\title{
RECURSOS FITOGENÉTICOS FORRAJEROS NATIVOS Y NATURALIZADOS PARA LOS BAJOS SUBMERIDIONALES:PROSPECCIÓN Y PRIORIZACIÓN DE ESPECIES PARA PLANES DE INTRODUCCIÓN A CULTIVO
}

\author{
Pensiero, J. F. ${ }^{1}$ \& Zabala, J. M. ${ }^{1}$
}

\begin{abstract}
RESUMEN
Los Bajos Submeridionales constituyen una extensa área del norte de Argentina que abarca cerca de 5 millones de has en las provincias de Santa Fe, Chaco y Santiago del Estero. La principal actividad productiva de los Bajos Submeridionales, y de los ambientes salinos en general, es la ganadería, la que se realiza en forma extensiva basada en el uso de los pastizales. Las limitantes ambientales que condicionan la producción de forraje son la salinidad de sus suelos y los períodos de inundaciones y sequías. La flora de los Bajos Submeridionales ofrece un número significativo de especies que deberían ser conservadas, estudiadas e introducidas a cultivo como recursos forrajeros. El trabajo menciona los elementos a considerar para desarrollo de un programa de introducción a cultivo de RFNyN para incrementar la oferta forrajera de los Bajos Submeridionales. La base del esquema reside en la identificación y caracterización de especies promisorias, aspectos en los que existen pocos trabajos a nivel nacional. Se presenta un listado de las mismas. Se discuten criterios de priorización y ejemplos de experiencias nacionales exitosas. El trabajo pone de relieve las actividades que deben encararse y las necesidades de trabajo interdisciplinario, cooperación entre diversos actores y financiamiento público.
\end{abstract}

Palabras clave: recursos genéticos, pastizales naturales, germoplasma, tolerancia a la salinidad.

1.-Programa de Documentación, Conservación y Valoración de la Flora Nativa. Facultad de Ciencias Agrarias, Universidad Nacional del Litoral.

Manuscrito recibido el 7 de octubre de 2016 y aceptado para su publicación el 17 de noviembre de 2016. 


\begin{abstract}
Native forage phytogenetic resources naturalized for the submeridional lowlands: Exploration and prioritization of species for farming introduction plans.

Submeridional Lowlands region is a large area covering 5 millions of hectare in Santa Fe, Chaco and Santiago del Estero provinces. Extensive cattle raising is the most important economic activity in the Submeridional Lowlands region. The main constraints of forage production are soil salinity and alternating flooding and drying cycles. Preserving grasslands that support commercial beef cattle production and the use of native and naturalized forage species to increase quantity and quality of forage become necessary. The flora of Submeridional Lowlands region contains a significant number of species that must be considered as forage genetic resources. This work examines different aspects to consider in breeding programs of native and naturalized forage species in the Submeridional Lowland Region. References about the identification and characterization of promissory species are scarce. We propose a list the native y naturalized species, which in our opinion, are important forage genetic resources. We discuss criteria of prioritization of the forage species in breeding programs and review successful examples of use of native and naturalized forage genetic resources in Argentina. We highlight keys aspects related with the interdisciplinary works, participatory plant breeding and public funding needs for conservation of native and naturalized plant genetic resources.
\end{abstract}

Key words: genetic resources, natural pastures, germplasm, salinity tolerance.

\section{INTRODUCCIÓN}

A partir del Convenio de Diversidad Biológica (CDB) de la Organización de las Naciones Unidas de 1992 ratificado en 1995 por Argentina, se definieron en su Artículo 2 algunos conceptos importantes que hasta el momento tenían varias acepciones.

Diversidad biológica: a la variabilidad de organismos vivos de cualquier fuente, incluidos los ecosistemas terrestres y marinos y otros ecosistemas acuáticos y los complejos ecológicos de los que forman parte; comprende la diversidad dentro de cada especie, entre las especies y de los ecosistemas.

Recursos biológicos: recursos genéticos, los organismos o partes de ellos, las poblaciones, o cualquier otro tipo del componente biótico de los ecosistemas de valor o utilidad real o potencial para la humanidad.

Recursos genéticos: todo material genético (de origen vegetal, animal, microbiano o de otro tipo que contenga unidades funcionales de la herencia) con valor real o potencial.

En dicho contexto, los recursos fitogenéticos comprenden la diversidad genética correspondiente al mundo vegetal que se considera poseedora de un valor para el presente o el futuro. Las especies vegetales nativas de Argentina, también denominadas autóctonas o indígenas, son aquéllas que ocurren como componentes naturales de la vegetación propia del país. Especies que, 